\title{
CONCEPT OF PRACTICE TEACHING TECHNICAL SUBJECTS FOR SECONDARY VOCATIONAL SCHOOLS TEACHING FACULTY AT MU
}

\section{Pavel PECINA}

Abstract: Methodology and Practice is a specific discipline, which is the subject profiled in the preparation of teachers of practical subjects at secondary vocational schools. The article is devoted to the specifics of this subject and its concepts and innovation in teacher training at the Pedagogical Faculty of Masaryk University.

Key words: didactics, didactics of practical training, vocational training

\section{ASPETY DIDAKTIKY PRAKTICKÉHO VYUČOVÁNÍ TECHNICKÝCH OBORŮ PRO STŘEDNÍ OSBORNÉ ŠKOLY NA PEDAGOGICKÉ FAKULTĚ MU}

Resumé: Didaktika praktického vyučování je specifickou disciplínou, která je profilovým předmětem při př́ípravě učitelů praktického vyučování na středních odborných školách. Článek je věnován specifikům tohoto předmětu a jeho pojetí a inovaci v rámci př́pravy učitelů na Pedagogické fakultě MU.

Klíčová slova: didaktika, didaktika praktického vyučování, odborný výcvik

\section{1 Úvod}

Didaktika praktického vyučování pro střední odborné školy je jedním z profilových předmětů při př́ípravě učitelů praktického vyučování a odborného výcviku technických oborů. $\mathrm{Na}$ katedře didaktických technologií Pedagogické fakulty MU se touto problematikou zabýváme již od 80. let 20. století. Předmět je vyučován $\mathrm{v}$ rámci trísemestrového doplňujícího pedagogického studia učitelství praktického vyučování (předmět zařazen do 3 . semestru) a dále potom $\mathrm{v}$ rámci šestisemestrového tř́letého bakalářského studia učitelství praktického vyučování. Cílem tohoto článku je seznámení se specifiky této disciplíny a jejím pojetím a inovací na Pedagogické fakultě MU.

\section{Pojetí didaktiky praktického vyučování}

Didaktika praktického vyučování je jedním $\mathrm{z}$ profilových předmětů $\mathrm{v}$ rámci pedagogického studia, oboru učitelství praktického vyučování. Tento obor má dvě interní specializace: obchod a služby a technické obory. Otázkám didaktiky praktického vyučování pro technické obory $\mathrm{v}$ rámci bakalářského studia se týmově věnujeme již od roku 2003. Svým charakterem předmět spadá do oborových didaktik a navazuje na obecně pedagogické a psychologické disciplíny. Významnou vazbu má i na didaktiku odborných předmětů na středních školách. $\mathrm{Na}$ výuce předmětu se kromě didaktiků katedry didaktických technologií podílí i zkušení učitelé z našich fakultních škol. Tito učitelé se uplatňují zejména při výuce cvičení a seminářù, kde mohou bohatě využít své dlouholeté zkušenosti $\mathrm{z}$ pedagogické praxe, což je $\mathrm{v}$ této oblasti velmi důležité. Předmět je prípravou pro vedení praktické (zpravidla dílenské) výuky na středních školách technických zaměření. Praktická prríprava je pro technické obory sohledem na budoucí praxi v oboru stěžejní částí př́ípravy.

V rámci bakalářského studia je předmět zařazen do čtvrtého a pátého semestru studia (jde tedy o dvousemestrovou př́ípravu). $\mathrm{Na}$ ni poté navazují následující předměty: Pedagogická praxe I (5. semestr), Pedagogická praxe II (6. semestr), semináŕ $\mathrm{z}$ didaktiky praktického vyučování (6. semestr). $Z$ tohoto hlediska je tedy teoretická a didaktická př́prava učitelů praktického vyučování rozsahem i obsahem dostačující. V současné době probíhá řešení projektu „Inovace bakalářského studijního oboru učitelství praktického vyučování“. Součástí projektu jsou následující klíčové aktivity:

- Inovace studijního plánu a vypracování modulového systému výuky.

- Inovace obsahové náplně vybraných stávajících předmětů (25 vybraných předmětů) a zpracování nových předmětů (5 předmětů).

- Zpracování učebních textů a výukových opor $\mathrm{k}$ inovovaným a novým předmětům.

- Inovace pedagogické praxe.

- Stáže akademických pracovníků. 
Inovovanými předměty jsou také didaktiky praktického vyučování pro technické obory. Bylo třeba aktualizovat obsahovou náplň předmětů v souladu s požadavky trhu práce a pedagogické praxe a zpracovat učební text (výukovou oporu) do tohoto předmětu. Vyhovující učební text ani výuková opora v současné době není k dispozici. Při inovaci vycházíme ze dvou studií, které jsou dnes již zastaralé [1], [2]. Při inovaci také vycházíme z provedeného výzkumného šetření, které bylo realizováno mezi studenty tohoto oboru i mezi učiteli praktického vyučování v praxi.

Obecným cílem předmětu je osvojení poznatků $\mathrm{z}$ problematiky cílů, obsahu, didaktických zásad, metod, forem a prostředků praktického vyučování $\mathrm{v}$ technických předmětech na středních odborných školách. Důležitá je aplikace teoretických poznatků z obecné didaktiky a psychologie na výuku praktického vyučování a odborného výcviku $\mathrm{v}$ technických předmětech na středních školách. Pozornost je zaměřena také na bezpečnost práce, školskou legislativu a další témata, související s prací učitele praktického vyučování, zejména propojení pedagogické teorie s pedagogickou praxí.

Inovovanou náplň předmětu tvoří následující stěžejní témata:

- Úvod do předmětu, vznik, vývoj a struktura didaktiky PV.

- Návaznost na koncepci pracovní výchovy na ZŠs.

- Teoretická východiska didaktiky PV.

- Vzdělávací soustava odborného výcviku.

- Soustava učebních a studijních oborů.

Zákony a vyhlášky platné pro zřizování, řízení a organizaci SOU a SOŠ - jejich aplikace.

- Kvalifikace a specifické požadavky.

- Problematika pedagogických cílů ve výuce odborného výcviku. Vymezování výcvikových a výchovných cílů.

- Základy učení senzomotorickým dovednostem.

- Uplatňování jednotlivých didaktických zásad, pouček a pravidel $\mathrm{v}$ praktickém vyučování.

- Obsah praktického vyučování.

Diferenciace učiva, základní a rozšiřující učivo. Složky učiva a jejich funkce, členění pracovního procesu a didaktické členění obsahu učiva. Výběr učiva podle obsahu pracovní činnosti $\mathrm{v}$ oboru. Modernizace obsahu učiva. Koordinace učiva, mezipředmětové vztahy.
- Systém výuky praktického vyučování.

- Pojetí učebního (studijního) oboru.

- Vyučovací prostředky praktického vyučování - úvod do problematiky.

- Nemateriální prostředky praktického vyučování.

- Výukové metody praktického vyučování.

- Organizační formy praktického vyučování.

- Materiální prostředky praktického vyučování - výrobní prostředky a předměty, modely, didaktická technika.

- Faktory ovlivňující volbu prostředků.

- Legislativa vztahující se $\mathrm{k}$ výuce praktického vyučování. Výchova $\mathrm{k}$ bezpečné práci a ochraně zdraví, výchova $\mathrm{k}$ péči o životní prostředí.

- Hodnocení v odborném výcviku. Hodnocení výsledků dosahovaných žáky, způsoby

- Hodnocení dílčích výsledků, souborných prací, cvičných a produktivních prací. Zadávání kontrolních prací a jejich hodnocení. Závěrečné a maturitní zkoušky.

- Vedení pedagogické dokumentace. Učební plány a učební osnovy odborného výcviku. Projektování výuky odborného výcviku.

- Odborná praxe žáků.

- Rozpracování tématického celku konkrétního oboru na základě učebních osnov odborného výcviku. Didaktická analýza učiva. Volba metod, forem a prostředků, postup a obsah př́pravy učitele praktického vyučování.

Předmět je ukončen zkouškou. $\mathrm{K}$ úspěšnému absolvování zkoušky je třeba prokázat znalost problematiky $\mathrm{v}$ rozsahu výše vymezených témat a zpracovat dvě práce (projekt výuky dvou výukových témat). Zkouška je písemná i ústní.

$\mathrm{V}$ rámci inovace jsme zapracovali zejména některá aktuální témata, problematiku školních vzdělávacích dokumentů a otázky související s aktuální platnou školskou legislativou. Velký důraz klademe na využití vybraných prostředků multimediální techniky, zejména videostudie $\mathrm{z}$ pedagogické praxe. Ve spolupráci $\mathrm{s}$ našimi fakultními školami natáćíme ukázkové vyučovací jednotky odborného výcviku, zpracujeme je a následně využíáme ve výuce. Součástí videostudií jsou zpracované didaktické podklady - metodické listy knahraným jednotkám. $\mathrm{S}$ ohledem na stanovené cíle $\mathrm{s}$ těmito materiály 
pracujeme ve výuce. Dále máme v plánu využít připravované výukové opory a $\mathrm{v}$ odpovídající míře i takové technologie jako 3D. V současné době již máme $\mathrm{k}$ dispozici bakalářské práce, které tuto technologii v odborném výcviku využívají [3].

\section{Závěr}

Didaktika praktického vyučování je rozhodujícím činitelem při př́ípravě učitelů technických oborů pro výuku praktického vyučování. Svým pojetím musí reflektovat zejména propojení pedagogické teorie s pedagogickou praxí a rozpracovávat specifika výuky praktického vyučování $\mathrm{v}$ technických oborech. Věříme, že po zavedení inovačních prvků bude výuka tohoto předmětu odpovídat reálným požadavkům trhu práce a požadavkům pedagogické praxe $\mathrm{v}$ této oblasti.

\section{Literatura}

[1] ČADÍLEK, M. Didaktika praktického vyučování I. Brno: CERM, s.r.o., 2003.

[2] STEJSKALOVÁ, P., ČADÍLEK, M. Didaktika praktického vyučování II. Brno: CERM, s.r.o., 2003.

[3] KREJČÍ, P. Inovace ŠVP Mechanik jednostopých vozidel. Bakalářská práce. Brno: Pedagogická fakulta MU, 2011.Vedoucí práce Ing. Milan Chylík.

Mgr. Pavel Pecina, Ph.D.

Katedra didaktických technologií

Pedagogická fakulta MU

Poříćí č. 7

61300, Brno, ČR

Tel: + 420549495488

E-mail: ppecina@ped.muni.cz

www pracoviště:

http://www.ped.muni.cz/winf/ 